\title{
Significance of Some Soil Amendments and Phosphate Dissolving Bacteria to Enhance the Availability of Phosphate in Calcareous Soil
}

\begin{abstract}
Ahmed A. Khalil
Soils, Water, and Environment Research Institute, Agricultural Research Centre, P.O. Box 175 El-Orman, Giza 12112, Egypt

Correspondence should be addressed to Ahmed A. Khalil; ahwafa@yahoo.com

Received 24 August 2013; Accepted 28 October 2013

Academic Editors: W. Ding and D. H. Phillips

Copyright (C) 2013 Ahmed A. Khalil. This is an open access article distributed under the Creative Commons Attribution License, which permits unrestricted use, distribution, and reproduction in any medium, provided the original work is properly cited.

A field experiment was carried-out on a private farm at the Salah El-Din village, El-Bostan district, Nobaria, El-Behera Governorate, Egypt. The aim of this study was to evaluate the best combination of rock phosphate (RP), sulphur (S), organic manure, and phosphate dissolving bacteria (PDB) inoculation to enhance the availability of phosphorous from rock phosphate and their effects on yield of broad bean plants (cv. Luz doe Otono L.). It was found that either sulphur application or PDB inoculation with RP had a significant effect on broad bean yield and its quality. Application of RP and different soil amendments individually or together increased N, P, and K contents in straw and seeds of broad bean plant. The highest contents of the studied nutrients were found when the plants were fertilized by a mixture of RP and different soil amendments. Results also showed the important role of organic matter, sulphur, and PDB for releasing phosphorus from rock phosphate. The combination of soil amendments with RP as a natural P-source, has the possibility of saving significant quantities of industrialized inorganic phosphate fertilizers.
\end{abstract}

\section{Introduction}

Broad bean (Vicia faba L.) is one of the most important legumes in Egypt. It is intensively used by both human and animals in many countries worldwide. It is considered as a cheap diet containing high protein and energy. Therefore, efforts to improve the quality and quantity of the vegetable crop are important. Under Egyptian soil conditions, phosphorus availability in soil is governed by many factors $\left(\mathrm{pH}, \mathrm{CaCO}_{3}\right.$, organic matter, and clay contents). In spite of the considerable addition of $\mathrm{P}$ to these soils, the level of available phosphorus decreases sharply after a short period since application. Under alkaline soil conditions, the available phosphorus in the added fertilizer is rapidly transformed to tricalcium phosphate which is unavailable to the plants [1]. Rock phosphate is the main source for producing phosphate fertilizers. The direct application of apatite $\mathrm{Ca}_{5}\left(\mathrm{PO}_{4}, \mathrm{CO}_{3}\right)_{3}(\mathrm{OH}, \mathrm{F})$ instead of phosphate fertilizers is not suitable, especially in soils with a high $\mathrm{pH}$. However, using acidic materials such as sulphur and sulphuric acid, or using rock phosphate combined with phosphate dissolving bacteria
(PDB) such as Pseudomonas, Azospirillum, Burkholderia, Bacillus, Enterobacter, Rhizobium, Erwinia, Serratia, Alcaligenes, Arthrobacter, Acinetobacter, and Flavobacterium which can produce some organic acids will release phosphorous from rock phosphate and can replace P-fertilizers. Gluconic acid was reported as the most frequent agent for mineral phosphate solubilization produced by Pseudomonas sp. and Erwinia herbicola [2,3].

Therefore, rock phosphate is a good source of phosphorus if organic manure and powdered sulphur with phosphate dissolving bacteria are added [4]. The addition of compost to the soils improves their physical, chemical, and biological properties, which influence the growth and development of plants. Also, organic acids produced from decomposition of organic matter help to dissolve the rock phosphate and increase the availability of phosphorus. Subehia (2001) found that the use of rock phosphate in conjunction with different organic manures was similar to the use superphosphate [5]. Sulphur oxidation in soils is an effective process in the reclamation of sodic soils in addition to providing the sulphur needs for plants. More importantly, this process will lower 
the $\mathrm{pH}$ of the soil resulting in an increased activity of some plant nutrients near the root zone and consequently resulting in an improvement in the yield and quality of agricultural crops. Kumar et al. (1992) reported the superiority of rock phosphate and sulphur compared to rock. Phosphate alone in increasing macro- and micronutrients in soils and decreasing soil $\mathrm{pH}$ which may be due to the oxidation of sulphur to sulphuric acid [6]. El-Sayed (1999) revealed that PDB plays an important role in releasing $\mathrm{P}$ from rock, tri-calcium, or other difficult $\mathrm{P}$-forms through the production of organic and inorganic acids, as well as $\mathrm{CO}_{2}$ [7]. These substances convert the insoluble forms of $\mathrm{P}$ into soluble ones. PDB also affects other nutrients in addition to phosphorus. For example, it was reported that seed inoculation with PDB generally increased number of total bacteria PDB in the rhizosphere zone and number of nodules and released ammonia from bound complex nitrogen compounds [8].

Therefore, the aim of this study was evaluating the efficiency of PDB, sulphur, and (organic manure) on release of phosphorus from rock phosphate and their effects on vegetative growth, chemical composition, and yield of broad bean plants.

\section{Materials and Methods}

A field experiment was carried-out in a private farm of the Salah El-Din village, El-Bostan district $\left(\begin{array}{lll}30^{\circ} 43^{\prime} 25.14^{\prime \prime} \mathrm{N} & \mathrm{N}\end{array}\right.$ $30^{\circ} 17^{\prime} 23.94^{\prime \prime}$ E elevation $14 \mathrm{~m}$ ), Nobaria, El-Behera Governorate, Egypt, during two successive winter growing seasons of 2008/2009 and 2009/2010. Soil samples were collected, prior to tillage from surface layer $(0-20 \mathrm{~cm})$ for physical and chemical analyses (Table 1). Furthermore, organic manure (compost) was analyzed according to Cottenie et al. (1982) and Page et al. (1982) (Table 2) [9, 10].

Each experiment included nine treatments arranged in a complete randomized block design (CRBD) with three replicates. Data was collected separately for both years from the individual treatments in the CRBD, analyzed statistically through analysis of variance over the year's techniques, and tables of variance were constructed. Averages of significant treatments were compared in accordance with Duncan's Multiple Range Test (DMR) at 5\% probability level. Seeds of broad bean (cv. Luz de Otono L.) were sown in hills spaced $20 \mathrm{~cm}$ apart on both sides of the ridge (planting line), under drip irrigation system.

For all treatments, phosphorus of two sources (super phosphate and rock phosphate) and sulphur were applied during seed bed preparation. Organic manure at a rate of $47.62 \mathrm{~m}^{3} /$ ha was uniformly incorporated into the soil layer at $20 \mathrm{~cm}$ depth with power tiller two weeks before planting. Plots received $47.62 \mathrm{~kg} \mathrm{~N}$ applied as a starter dose in the form of ammonium sulphate $(20.6 \% \mathrm{~N})$ after thinning as well as $57.14 \mathrm{~kg} \mathrm{~K} \mathrm{~K}_{2} \mathrm{O}$ applied in the form of potassium sulphate (48\% $\mathrm{K}_{2} \mathrm{O}$ ).

The treatments were as follows:

(1) $357.4 \mathrm{~kg}$ applied super phosphate $\left(15 \%\right.$ soluble $\mathrm{P}_{2} \mathrm{O}_{5}$ ) at a rate of $53.57 \mathrm{~kg} / \mathrm{ha} \mathrm{P}_{2} \mathrm{O}_{5}$;
TABLE 1: Some physical and chemical properties of the experimental soil.

\begin{tabular}{lc}
\hline Property & Content \\
\hline Moisture content (\%) & 13.00 \\
EC $(\mathrm{dS} / \mathrm{m})$ & 3.80 \\
$\mathrm{pH}(1: 10)$ & 7.50 \\
Total N (\%) & 0.78 \\
Total P (\%) & 0.52 \\
Total K (\%) & 1.68 \\
C/N ratio & $1: 22.70$ \\
Organic matter (\%) & 30.55 \\
Organic carbon $(\%)$ & 17.71 \\
\hline
\end{tabular}

TABLE 2: Some properties of the used organic manure (compost).

\begin{tabular}{|c|c|}
\hline Characters & Value \\
\hline \multicolumn{2}{|c|}{ Particle size distribution (\%) } \\
\hline Sand & 65.18 \\
\hline Silt & 18.51 \\
\hline Clay & 16.31 \\
\hline Textural class & Sandy loam \\
\hline $\mathrm{CaCO}_{3}(\%)$ & 22.30 \\
\hline \multicolumn{2}{|l|}{ Chemical analysis } \\
\hline $\mathrm{pH}(1: 2.5)$ & 8.15 \\
\hline $\mathrm{EC}(\mathrm{dS} / \mathrm{m}) 1: 5$ & 0.53 \\
\hline \multicolumn{2}{|c|}{ Soluble ions (meq/100 g soil) } \\
\hline $\mathrm{Ca}^{++}$ & 0.37 \\
\hline $\mathrm{Mg}^{++}$ & 0.16 \\
\hline $\mathrm{Na}^{+}$ & 0.58 \\
\hline $\mathrm{K}^{+}$ & 0.08 \\
\hline $\mathrm{CO}_{3}^{--}$ & 0.00 \\
\hline $\mathrm{HCO}_{3}^{-}$ & 0.30 \\
\hline $\mathrm{Cl}^{-}$ & 0.59 \\
\hline $\mathrm{SO}_{4}^{--}$ & 0.30 \\
\hline Organic matter (\%) & 0.26 \\
\hline Organic carbon (\%) & 0.15 \\
\hline \multicolumn{2}{|l|}{ Total (\%) } \\
\hline $\mathrm{N}$ & 0.04 \\
\hline $\mathrm{P}$ & 0.12 \\
\hline $\mathrm{K}$ & 1.21 \\
\hline \multicolumn{2}{|c|}{ Available contents (mg/kg soil) } \\
\hline $\mathrm{N}$ & 11.7 \\
\hline $\mathrm{P}$ & 3.32 \\
\hline $\mathrm{K}$ & 70.0 \\
\hline $\mathrm{Fe}$ & 3.61 \\
\hline $\mathrm{Zn}$ & 0.52 \\
\hline $\mathrm{Mn}$ & 0.44 \\
\hline
\end{tabular}

(2) $191.93 \mathrm{~kg}$ applied rock phosphate (RP) (28\% total $\mathrm{P}_{2} \mathrm{O}_{5}$ ) at a rate of $53.57 \mathrm{~kg} / \mathrm{ha} \mathrm{P}_{2} \mathrm{O}_{5}$;

(3) $\mathrm{RP}+476.19 \mathrm{~kg} \mathrm{~S} / \mathrm{ha}$;

(4) RP + PDB (seed inoculation with PDB just before sowing); 
(5) $\mathrm{RP}+47.62 \mathrm{~m}^{3} / \mathrm{ha} \mathrm{OM}$ (organic manure);

(6) $\mathrm{RP}+\mathrm{PDB}+476.19 \mathrm{~kg} \mathrm{~S} / \mathrm{ha}$;

(7) $\mathrm{RP}+476.19 \mathrm{~kg} \mathrm{~S} / \mathrm{ha}+47.62 \mathrm{~m}^{3} / \mathrm{ha} \mathrm{OM}$;

(8) $\mathrm{RP}+\mathrm{PDB}+47.62 \mathrm{~m}^{3} / \mathrm{ha} \mathrm{OM}$;

(9) $\mathrm{RP}+\mathrm{PDB}+476.19 \mathrm{~kg} \mathrm{~S} / \mathrm{ha}+47.62 \mathrm{~m}^{3} / \mathrm{ha} \mathrm{OM}$.

Broad bean plants were harvested and the following characteristics were recorded:

(1) total weight of green pods/plant (g);

(2) number of pods/plant;

(3) dry weight of seeds/plant (g);

(4) 100-seed weight (g) (the 100-seed weight is a measure of seed size. It is the weight in grams of 100 -seeds. Seed size and the 100-seed weight can vary from one crop to another, between varieties of the same crop and even from year to year or from field to field of the same variety. Because of this variation in seed size, the number of seeds and, consequently, the number of plants in a pound or a bushel of seed are also highly variable. By using the 100 -seed weight, a producer can account for seed size variations when calculating seeding rates, calibrating seed drills, and estimating shattering and combine losses);

(5) seed and straw yields ( $\mathrm{kg} / \mathrm{ha})$.

From each plot, samples of both seeds and straw were oven dried $\left(70^{\circ} \mathrm{C}\right)$; ground and wet digested using a $1: 1$ mixture of $\mathrm{H}_{2} \mathrm{SO}_{4}$ and $\mathrm{HClO}_{4}$ acids $(V / V)$. In the digested product, nitrogen content of the plants (straw and seeds) was determined by Kjeldahl method while potassium content was determined by flame photometer [11]. Phosphorus content of plant parts was determined by a colorimetric method [12]. Moreover, the biochemical constituents in broad bean seeds such as protein and carbohydrate were estimated using the methods outlined by A.O.A.C. (1990) [13]. All collected data were statistically analyzed according to K. A. Gomez and A. A. Gomez (1984) [14].

\section{Results and Discussion}

3.1. Effect of the Applied Treatments on Yield and Its Components. Results presented in Table 3 showed that total weight of green pods/plant, number of pods/plant, dry weight of seeds/plant, 100-seed weight, seed and straw yield, seed protein (\%), protein yield, and total carbohydrate (\%) were significantly affected $(P<0.05)$ by RP in combination with soil amendments ( $S$ and organic manure) and PDB either added individually or in combinations. However, the greatest values were associated with applied combined treatment of (PDB + compost $+\mathrm{S})$. The corresponding relative percentages increases reached $34.03 \%, 22.45 \%, 23.26 \%, 6.64 \%$, $41.99 \%, 41.34 \%, 7.95 \%, 53.28 \%$, and $9.71 \%$ over the control treatment (SP\%), respectively. These increases in yield and its components of broad bean plants may be attributed to the increases in both cell division and cell elongation. As reported earlier, phosphorus plays a major role in protein synthesis and protoplasm formation. It may increase the proportion or protoplasm to cell wall, and it is a part of the molecular structure of nucleic acids DNA and RNA resulting in an increment in vegetative growth characters like increased cell size $[15,16]$. In addition, phosphorus plays an important role in photosynthesis and respiration, and it is also essential for division and development of meristematic tissues. Similar results were previously reported $[17,18]$. Seed inoculation with the PDB caused remarkable increases in most parameters as compared with rock phosphate fertilizer only.

These increases may be due to the inoculation with phosphate dissolving bacteria which solubilized unavailable forms of calcium bound phosphate by excreting organic acids such as gluconic acid, formic, acetic, lactic, propionic, fumaric, and succinic acids, those acids are lowering the $\mathrm{pH}$ which directly bring in insoluble phosphates in soil into soluble forms as well as the displacement of phosphorous on surfaces [8, 19-22]. There are indications that these bacteria may also produce growth promoting substances such as auxins, gibberellins, and cytokinins. Such substances could influence the plant growth by making the roots able to explore more soil and more zones where phosphate ions were chemically liberated from the P-source. Similar positive effects of PDB have been obtained on soybean, lentil, and mung bean $[7,8,23]$.

Concerning the interactive effects of treatments, data showed that the application of two amendments was more effective than a single one, while the tricombinations had the most effect on enhancing the yield and yield components. Also, the same effect of elemental sulphur application and inoculation with PDB in the presence of RP on yield and its components had been observed. This could be attributed to the vital role of combined treatments in reducing soil $\mathrm{pH}$, enhancing nutrient uptake, chlorophyll content, and photosynthetic rate which impacted growth and plant characteristics [24-26]. Sulphur has an important role in the formation of plant proteins and some hormones, as well as being necessary for enzymatic action, chlorophyll formation, and synthesis of certain amino acids and vitamins $[19,20]$. Hence, sulphur is important for good vegetative growth leading to a high yield and increasing absorption of macroand micronutrients. This is through its oxidation to sulphuric acid by soil microorganisms leading to the solubilization and availability of nutrients to plants [16, 27, 28]. Also, Table 3 showes the effect of soil amendments, that is, organic and sulphur on broad bean yield (seed and straw), yield components, as well crude as protein and carbohydrate (\%). In general, the increase in (seed and straw) yield due to the addition of organic manure, which increase the availability of nutrients in soil during the decomposition process and produced $\mathrm{CO}_{2}$, plays an important role in increasing phosphorus availability $[2,3]$.

Furthermore, the addition of organic manure significantly affected all studied characteristics of broad bean plants as being a source for all essential macro- and micronutrients. It plays a direct role for meliorating soil hydrophysical properties such as soil aggregation, bulk density, total porosity, aeration, hydraulic conductivity and available water range. Soil chemical characteristics such as soil $\mathrm{pH}$, released organic 


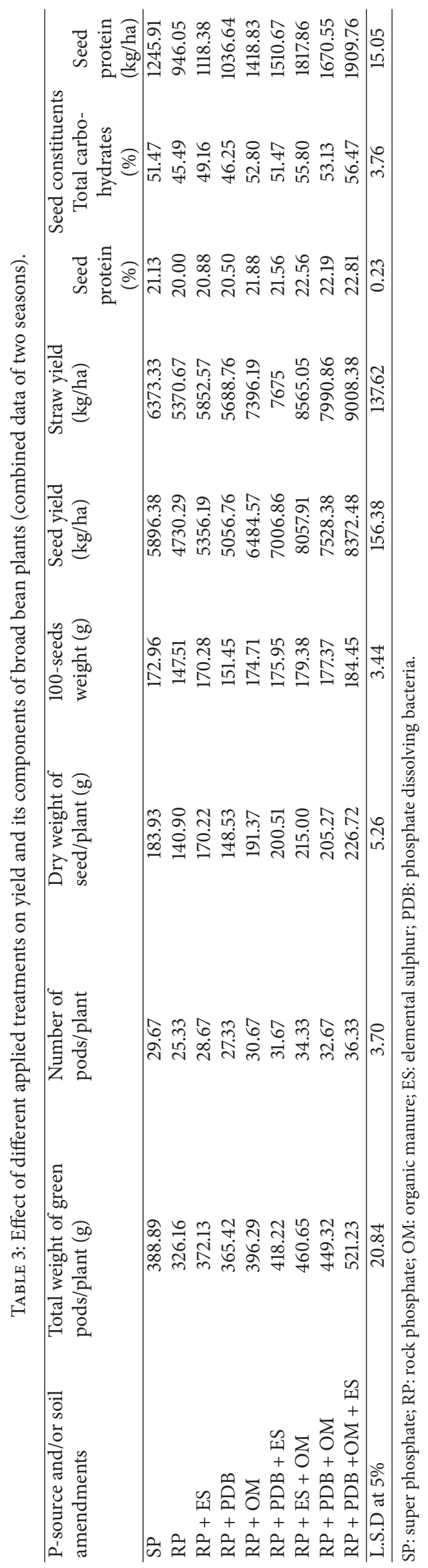


TABLE 4: Effect of different applied treatments on NPK total content $(\mathrm{kg} / \mathrm{ha})$ of broad bean plants (combined data of two seasons).

\begin{tabular}{|c|c|c|c|c|c|c|c|c|c|}
\hline \multirow{2}{*}{$\begin{array}{l}\text { P-source and/or soil } \\
\text { amendments }\end{array}$} & \multicolumn{3}{|c|}{ Nitrogen total content $(\mathrm{kg} / \mathrm{ha})$} & \multicolumn{3}{|c|}{ Phosphorous total content $(\mathrm{kg} / \mathrm{ha})$} & \multicolumn{3}{|c|}{ Potassium total content $(\mathrm{kg} / \mathrm{ha})$} \\
\hline & Seed & Straw & Total & Seed & Straw & Total & Seed & Straw & Total \\
\hline SP & 199.29 & 93.69 & 292.98 & 21.81 & 14.02 & 35.83 & 34.19 & 141.48 & 175.67 \\
\hline $\mathrm{RP}$ & 151.38 & 75.19 & 226.57 & 9.93 & 7.52 & 17.45 & 23.64 & 114.93 & 138.57 \\
\hline $\mathrm{RP}+\mathrm{ES}$ & 178.9 & 84.86 & 263.76 & 18.74 & 12.29 & 31.02 & 29.45 & 128.76 & 158.21 \\
\hline $\mathrm{RP}+\mathrm{PDB}$ & 165.86 & 81.93 & 247.79 & 14.67 & 10.24 & 24.90 & 26.81 & 124.02 & 150.83 \\
\hline $\mathrm{RP}+\mathrm{OM}$ & 226.95 & 114.64 & 341.6 & 25.29 & 17 & 42.29 & 42.14 & 169.38 & 211.52 \\
\hline $\mathrm{RP}+\mathrm{PDB}+\mathrm{ES}$ & 241.74 & 121.26 & 363 & 31.52 & 19.19 & 52 & 43.45 & 172.69 & 216.14 \\
\hline $\mathrm{RP}+\mathrm{ES}+\mathrm{OM}$ & 290.88 & 140.93 & 431.81 & 39.48 & 23.07 & 62.55 & 54.79 & 200.71 & 255.5 \\
\hline $\mathrm{RP}+\mathrm{PDB}+\mathrm{OM}$ & 267.26 & 129.45 & 396.71 & 35.38 & 20.79 & 56.17 & 52.69 & 194.98 & 247.67 \\
\hline $\mathrm{RP}+\mathrm{PDB}+\mathrm{OM}+\mathrm{ES}$ & 305.6 & 152.24 & 457.83 & 46.05 & 25.21 & 71.26 & 60.29 & 224.31 & 284.57 \\
\hline L.S.D at $5 \%$ & 2.45 & 1.74 & 3.12 & 1.57 & 1.67 & 2.36 & 1.86 & 3.31 & 3.29 \\
\hline
\end{tabular}

constituents of active groups such as fulvic and humic acids able to retain the essential plant nutrients in complex and available chelated forms are also impacted by the organic manure. Organic manure affects soil biological conditions. That is, a source of energy for the microorganism activities which enhance the release of necessary nutrients in available forms throughout their mineralization, in return improves soil fertility status (i.e., slow release of nutrients) which support root development among the different growth stages, and finally leads to higher yield and its content of broad bean plants. Similar results were gained previously $[27,29,30]$.

\subsection{Effect of Different Applied Treatments on NPK Contents of} Broad Bean Plant. The data presented in Table 4 shows broad bean seeds and straws differ significantly in their uptake of $\mathrm{N}, \mathrm{P}$, and $\mathrm{K}$ as a result of the applied treatments. The highest $\mathrm{N}$, P, and $\mathrm{K}$ contents of broad bean plants were recorded from plants received soil amendments combined with RP compared with RP only. Phosphorus uptake was higher in plants fertilized with RP in combination with biofertilizer (PDB) or fertilized with organic manure as compared to those that received RP only. This is because since organic manure and PDB inoculation increased the efficiency of phosphorus released in low phosphate source, this is due to the release of organic acids, $\mathrm{pH}$ reduction, and/or dissolution the mineral phosphate through the anion exchange of (PO4)-3 or due to the chelating property of the organic acid produced by PDB such as acetate, lactate, oxalate, and citrate [31]. Moreover, application of $\mathrm{P}$ increases its concentration in the vicinity of plant roots and its availability in the soil solution as well as reduces its fixation by soil factors resulting from the introduction of most $\mathrm{P}$ requirements at preplanting in a limited zone, where root growth is highly concentrated.

Application of PDB increased the uptake of $\mathrm{N}$ and $\mathrm{K}$ for building new tissues [8]. The positive effect of $\mathrm{P}$ application on $\mathrm{N}$ contents in different parts of broad bean plants can be attributed to increase of the nodular number, size, and mass, which in turn increases $\mathrm{N}_{2}$-fixation by bacteria [32].
Marschner (1986) described the enhancing effect of P on K uptake to the energy rich phosphates (in the form ATP) and the close relationship between K-uptake and the ATP-ase activity [33].

The maximum increase percentage was obtained by mixing soil amendments combined with RP, which resulted in increments of $53.35 \%, 111.14 \%$, and $76.32 \%$, respectively, in N, P and K-uptake of broad bean seeds and $62.49 \%, 79.80 \%$, and $58.55 \%$, respectively, in N, P and K-uptake of broad bean straw as compared with the control treatment (SP). Also, the data showed that a combination of two amendments was more effective than a single one, while a combination of all three had the most effect, for enhancing the nutrients taken up by seeds and straw of broad bean. Such effect of sulphur amendment on nutrients uptake may be due to its important role in reducing the soils' $\mathrm{pH}$, oxidation to sulphuric acid by soil microorganisms. Subsequently, this results in solubilization and availability of nutrients to plants. Also, under those experimental conditions, it was concluded that application of organic manure to sandy loam soil increased the efficiency of P mineral from the RP fertilizers used. It improves the physical and chemical properties of sandy soil through its ability to adsorb nutrients on active groups or colloidal surfaces and increased the efficiency of nutrients uptake by plants reflected on growth and productivity. These results are in agreement with those of S. N. Sahu and B. B. Jana (2000) and Evans et al. (2006) [34, 35].

In conclusion, the addition of soil amendments and bio fertilizer to sand loamy soil improved the estimated parameters reflecting improved soil available nutrients, chemical, and physical soil properties. Applied soil amendments gave a significantly positive effect than the control. The combined treatments of $\mathrm{OM}$ and $\mathrm{S}$ and $\mathrm{PDB}$ gave highly significant increases in yield and nutrient contents of broad bean as compared to their individual application. The most effective treatment was RP and S and OM or RP and PDB and S and OM which achieved the highest yield parameters and N, P, and $\mathrm{K}$ contents of seeds and straw of broad bean as compared to the control. 


\section{References}

[1] R. W. Miller, R. L. Danhaue, and J. U. Miller, An Introduction to Soil and Plant Growth, Prentice Hall International, London, UK, 6th edition.

[2] P. Illmer and F. Schinner, "Solubilization of inorganic phosphates by microorganisms isolated from forest soils," Soil Biology and Biochemistry, vol. 24, no. 4, pp. 389-395, 1992.

[3] S.-T. Liu, L.-Y. Lee, C.-Y. Tai et al., "Cloning of an Erwinia herbicola gene necessary for gluconic acid production and enhanced mineral phosphate solubilization in Escherichia coli HB101: nucleotide sequence and probable involvement in biosynthesis of the coenzyme pyrroloquinoline quinone," Journal of Bacteriology, vol. 174, no. 18, pp. 5814-5819, 1992.

[4] M. Lotfollahi, M. J. Malakout, K. Khavazi, and H. Besharat, "Effect of different methods of direct application of rock phosphate on the yield of feed corn in Karaj region," Journal of Soil and Water, vol. 12, pp. 11-15, 2001.

[5] S. K. Subehia, "Direct and residual effect of Udaipur rock phosphate as a source of $\mathrm{P}$ to wheat soybean cropping System in a Western Himalayan soil," Research on Crop, vol. 2, pp. 297300, 2001.

[6] V. Kumar, R. J. Gilkes, and M. D. A. Bolland, "The residual value of rock phosphate and superphosphate from field sites assessed by glasshouse bioassay using three plant species with different external P requirements," Fertilizer Research, vol. 32, no. 2, pp. 195-207, 1992.

[7] S. A. M. El-Sayed, "Influence of Rhizobium and phosphate solubilization bacteria on nutrient uptake and yield of lentil in New Valley," Egyptian Journal of Soil Science, vol. 39, pp. 175-186, 1999.

[8] K. Nassar, M. Y. Gebrail, and K. M. Khalil, "Efficiency of phosphate dissolving bacteria (PDB) combined with different forms and rates of $\mathrm{P}$ fertilization on the quantity and quality of Faba bean (Vicia Faba L.)," Menoufya Journal of Agricultural Research, vol. 25, pp. 1335-1349, 2000.

[9] A. Cottenie, M. Verloo, L. Kiekens, G. Velghe, and R. Camerlynck, "Chemical Analysis of Plants and Soils," Lab. Anal. Agrochem. Faculty of Agriculture, State University Gent, Gent, Belgium, 1982.

[10] A. L. Page, R. H. Miller, and D. R. Keeny, Methods of Soil Analysis-part 2: Chemical and Microbiological Properties, American Society of Agronomy, Madison, Wis, USA, 2nd edition, 1982.

[11] H. D. Chapman and P. F. Pratt, "Methods of Analysis for Soils, Plants and Waters," The University of California's Division of Agriculture Sciences, Davis, Calif, USA, 1961.

[12] E. Troug and K. H. Mayer, "Improvements in the Denige; chloromeric method for phosphorous and srsenic," Industrial and Engineering Chemistry, vol. 1, pp. 136-139, 1949.

[13] A.O.A.C., Official Methods of Analysis, Association of Official Agricultural Chemists, Washington, DC, USA, 15 edition, 1990.

[14] K. A. Gomez and A. A. Gomez, Statistical Procedures for Agricultural Research, John Wiley \& Sons, New York, NY, USA, 1984.

[15] K. Mengel and E. A. Kirkby, "Principles of Plant Nutrition," International Potash Institute, Bern, Switzerland, 1987.

[16] H. Marschner, Mineral Nutrition of Higher Plants, Harcourt Brace and Company, London, UK, 1998.

[17] A. A. Abdul-Galil, E. M. El-Naggar, H. A. Awad, and T. S. Mokhtar, "Response of two faba bean cultivars to different N,
P and K levels under sandy soil conditions," Zagazig Journal of Agricultural Research, vol. 5, pp. 1787-1808, 2003.

[18] F. A. Abdo, "Effect of bio-fertilizer with phosphate dissolving bacteria under different levels of phosphorus fertilization on mung bean plant," Journal of Agricultural Research, vol. 30, pp. 187-211, 2003.

[19] B. S. Kundu and A. C. Gaur, "Rice response to inoculation with N2-fixing and P-solubilizing microorganisms," Plant and Soil, vol. 79, no. 2, pp. 227-234, 1984.

[20] M. Monib, I. Hosny, and Y. B. Besada, "Seed inoculation of castor oil plant (Ricinus communis) and effect on nutrient uptake," Soil Biology and Conservation of the Biosphere, vol. 2, pp. 723-732, 1984.

[21] S. A. Azer, A. M. Awad, Sadek et al., "A comparative study on the effect of elements and bio-phosphatic fertilizers on the response of Faba bean (Vicia Faba L.) to P fertilization," Egyptian Journal of Applied Science, vol. 18, pp. 324-363, 2003.

[22] M. A. Ewais, "Response of vegetative growth, seed yield and quality of peanut grown on a sandy soil to application of organic manure, inoculation with rhizobium and phosphate dissolving bacteria," Egyptian Journal of Applied Science, vol. 21, pp. 794816, 2006.

[23] E. M. Abd El Lateef, M. M. Selim, and T. G. Behairy, "Response of some oil crops to bio-fertilization with phosphate dissolving bacteria associated with different levels of phosphatic fertilization," Bulletin of National Research Center (NRC), vol. 23, pp. 193-202, 1998.

[24] A. M. Hewedy, "Effect of sulphur application and biofertilizer phosphorein on growth and productivity of tomato," Minufiya Journal of Agricultural Research, vol. 24, pp. 1063-1078, 1999.

[25] H. A. El-Shamma, "Effect of chemical and bio-fertilizer on growth, seeds and quality of new cv. of dry bean," Annals of Agricultural Science, vol. 38, pp. 461-468, 2000.

[26] T. G. A. Ali, Effect of some agriculture treatments on growth and dry seeds yield of bean [M. S. thesis], Faculty of Agriculture, Minia University, Minia Governorate, Egypt, 2002.

[27] F. S. Salem, "Effect of some soil amendment on the clayey soil properties and some crops production," Menoufya Journal of Agricultural Research, vol. 28, pp. 1705-1715, 2003.

[28] F. S. Salem, M. Y. Gebrail, M. O. Easa, and M. Abd El-Warth, "Raising the efficiency of nitrogen fertilization for wheat plants under salt affected soils by applying some soil amendments," Menoufya Journal of Agricultural Research, vol. 29, pp. 10591073, 2004.

[29] S. M. Abdel Aziz, F. S. Salem, M. A. Reda, and L. A. Hussien, "Influence of some amendments on the clayey soil properties and crop production," Fayaum Journal of Agricultural Research and Development, vol. 12, pp. 196-204, 1998.

[30] S. E. A. Mohamed and S. S. S. El-Ganaini, "Effect of organic, mineral and bio-fertilizers on growth, yield and chemical constituents as well as the anatomy of broad bean (Vicia Faba L.) in reclaimed soil," Egyptian Journal of Applied Science, vol. 18, pp. 38-63, 2003.

[31] A. Abd El Latif, M. Maged, A. Ewais, A. A. Mahmoud, and M. M. Hanna, "The response of maize to organic manure, bio-fertilizer and foliar spray with citric acid under sandy soil condition," Egyptian Journal of Applied Science, vol. 20, pp. 661681, 2005.

[32] B. Y. El-Koumey, E. S. Abou Husien, and F. S. El-Shafie, "Influence of phosphatic fertilizers on NPK and some heavy metals in soil and plant," Zagazig Journal of Agricultural Research, vol. 20, pp. 2029-2044, 1993. 
[33] H. Marschner, Mineral Nutrition of Higher Plants, Harcourt Brace Javanovich, London, UK, 1986.

[34] S. N. Sahu and B. B. Jana, "Enhancement of the fertilizer value of rock phosphate engineered through phosphate-solubilizing bacteria," Ecological Engineering, vol. 15, no. 1-2, pp. 27-39, 2000.

[35] J. Evans, L. McDonald, and A. Price, "Application of reactive phosphate rock and sulphur fertilisers to enhance the availability of soil phosphate in organic farming," Nutrient Cycling in Agroecosystems, vol. 75, no. 1-3, pp. 233-246, 2006. 

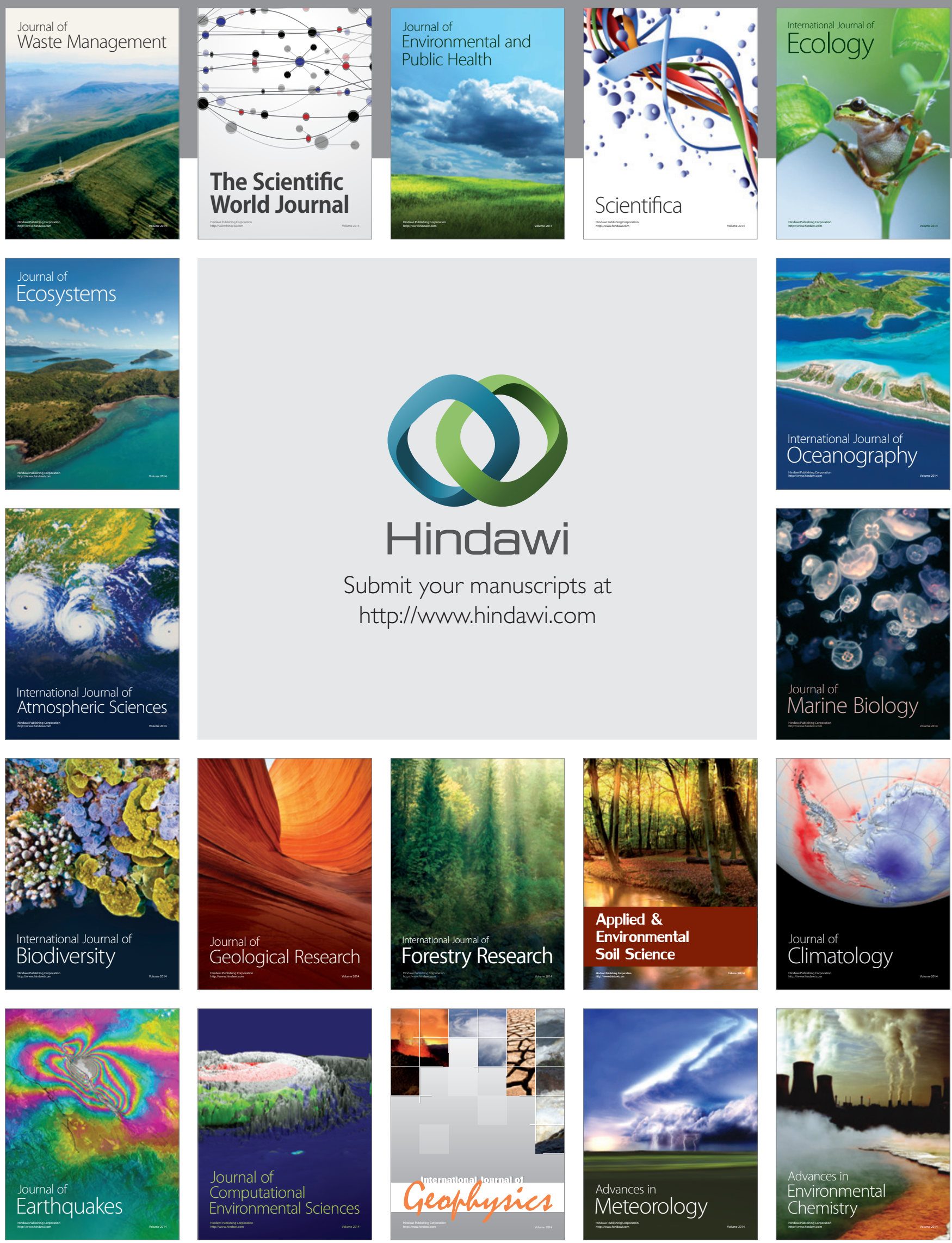